\title{
Persistency of methane mitigation by dietary nitrate supplementation in dairy cows
}

\author{
S. M. van Zijderveld, ${ }^{* 1}$ W. J. J. Gerrits, † J. Dijkstra,† J. R. Newbold, ${ }^{*}$ R. B. A. Hulshof, ${ }^{*}$ and H. B. Perdok ${ }^{*}$ \\ ${ }^{*}$ Provimi Holding B.V., Research Centre De Viersprong, Veilingweg 23, NL-5334LD, Velddriel, the Netherlands \\ †Animal Nutrition Group, Wageningen University, PO Box 338, $6700 \mathrm{AH}$ Wageningen, the Netherlands
}

\begin{abstract}
Feeding nitrate to dairy cows may lower ruminal methane production by competing for reducing equivalents with methanogenesis. Twenty lactating HolsteinFriesian dairy cows $(33.2 \pm 6.0 \mathrm{~kg}$ of milk/d; $104 \pm$ $58 \mathrm{~d}$ in milk at the start of the experiment) were fed a total mixed ration (corn silage-based; forage to concentrate ratio 66:34), containing either a dietary urea or a dietary nitrate source $[21 \mathrm{~g}$ of nitrate/ $\mathrm{kg}$ of dry matter (DM)] during 4 successive 24-d periods, to assess the methane-mitigating potential of dietary nitrate and its persistency. The study was conducted as paired comparisons in a randomized design with repeated measurements. Cows were blocked by parity, lactation stage, and milk production at the start of the experiment. A 4-wk adaptation period allowed the rumen microbes to adapt to dietary urea and nitrate. Diets were isoenergetic and isonitrogenous. Methane production, energy balance, and diet digestibility were measured in open-circuit indirect calorimetry chambers. Cows were limit-fed during measurements. Nitrate persistently decreased methane production by $16 \%$, whether expressed in grams per day, grams per kilogram of dry matter intake (DMI), or as percentage of gross energy intake, which was sustained for the full experimental period (mean 368 vs. $310 \pm 12.5 \mathrm{~g} / \mathrm{d} ; 19.4$ vs. $16.2 \pm$ $0.47 \mathrm{~g} / \mathrm{kg}$ of DMI; 5.9 vs.4.9 $\pm 0.15 \%$ of gross energy intake for urea vs. nitrate, respectively). This decrease was smaller than the stoichiometrical methane mitigation potential of nitrate (full potential $=28 \%$ methane reduction). The decreased energy loss from methane resulted in an improved conversion of dietary energy intake into metabolizable energy ( 57.3 vs. $58.6 \pm 0.70 \%$, urea vs. nitrate, respectively). Despite this, milk energy output or energy retention was not affected by dietary nitrate. Nitrate did not affect milk yield or apparent digestibility of crude fat, neutral detergent fiber, and starch. Milk protein content (3.21 vs. $3.05 \pm 0.058 \%$, urea vs. nitrate respectively) but not protein yield was
\end{abstract}

Received February 4, 2011.

Accepted April 18, 2011.

${ }^{1}$ Corresponding author: svanzijderveld@nl.provimi.com lower for dietary nitrate. Hydrogen production between morning and afternoon milking was measured during the last experimental period. Cows fed nitrate emitted more hydrogen. Cows fed nitrate displayed higher blood methemoglobin levels (0.5 vs. $4.0 \pm 1.07 \%$ of hemoglobin, urea vs. nitrate respectively) and lower hemoglobin levels $(7.1$ vs. $6.3 \pm 0.11 \mathrm{mmol} / \mathrm{L}$, urea vs. nitrate respectively). Dietary nitrate persistently decreased methane production from lactating dairy cows fed restricted amounts of feed, but the reduction in energy losses did not improve milk production or energy balance.

Key words: methane, nitrate, dairy cow

\section{INTRODUCTION}

The production of ruminant meat and milk is associated with a relatively high production of greenhouse gases (GHG) compared with other food commodities (Williams et al., 2008). In a recent publication, the contribution of the dairy sector to the global production of greenhouse gases was estimated to be 2.7\% (FAO, 2010). This high level of GHG production is mainly related to the anaerobic fermentation of fiber-rich feedstuffs in the gastrointestinal tract of ruminants. Methane production from enteric fermentation accounts for $52 \%$ of the carbon footprint of milk, expressed in $\mathrm{CO}_{2^{-}}$ equivalents, at the farm gate (FAO, 2010). A decrease in the amount of enteric methane could substantially decrease the amount of GHG associated with milk production. Although many dietary strategies have been proposed to decrease methane production from ruminants (Martin et al., 2010), few have shown a persistent decrease of methane production in vivo. Persistency of the methane-decreasing effect is an absolute requirement for any dietary strategy to be successful in abating GHG emissions from ruminants.

Most methane production during rumen fermentation is the result of the reduction of $\mathrm{CO}_{2}$ with $\mathrm{H}_{2}$ by methanogenic Archaea residing in the rumen. This process enables the removal of excess $\mathrm{H}_{2}$ from the rumen and allows NADH to be reconstituted to $\mathrm{NAD}^{+}$, a process essential to the continuation of anaerobic rumen fermentation and microbial growth (Wolin, 1975). 
Anaerobic nitrate reduction is energetically more favorable than $\mathrm{CO}_{2}$ reduction, and the presence of nitrate in the rumen redirects $\mathrm{H}_{2}$ from methanogenesis to nitrate reduction, thereby decreasing methane production (Allison and Reddy, 1984). However, the sudden introduction of nitrate into ruminant diets may lead to the occurrence of methemoglobinemia, a condition caused by the oxidation of the ferric iron in hemoglobin, rendering the molecule incapable of oxygen transport. The oxidation of hemoglobin is caused by the presence of nitrite, an intermediate in nitrate reduction, in blood. Gradual introduction of nitrate into the diet can allow the rumen microbes to adapt and increase their capability to reduce nitrite (Alaboudi and Jones, 1985). van Zijderveld et al. (2010), using a 4-wk adaptation period to dietary nitrate, demonstrated decreased methane emissions $(-32 \%)$ in sheep fed nitrate, while methemoglobinemia was not observed. Similarly Nolan et al. (2010) used an 18-d adaptation period and observed a $23 \%$ decrease in methane emissions in sheep fed nitrate, again without the occurrence of methemoglobinemia. The effect of feeding nitrate to dairy cows on enteric methane production has not yet been investigated. In addition, it is unknown if the methane-depressing effect of nitrate persists over time.

This experiment was designed to investigate to what extent dietary nitrate can decrease enteric methane production in lactating dairy cows and if this would affect animal productivity, feed digestibility, or energy balance. After a 4-wk adaptation period, methane production was measured in 4 consecutive periods with 24-d intervals to investigate if the methane decrease caused by dietary nitrate was persistent.

\section{MATERIALS AND METHODS}

\section{Experimental Design}

The Animal Care and Use Committee of Wageningen University (Wageningen, the Netherlands) approved the experimental protocol. The experiment was designed as a completely randomized block with repeated measurements. Twenty Holstein-Friesian dairy cows were blocked according to parity, lactation stage, and milk production at the start of the experiment and subsequently within a block randomly allocated to 1 of 2 diets. One diet (hereafter, the nitrate diet) contained a nitrate source (Calcinit, Yara, Oslo, Norway) which was replaced by urea, on an isonitrogenous basis, in the other diet (the urea diet).

\section{Animals and Housing}

The experiment was conducted at the experimental dairy farm of Wageningen University and Research
(Wageningen, the Netherlands). The experimental group included 20 lactating Holstein-Friesian dairy cows (initial milk production $33.2 \pm 6.0 \mathrm{~kg} ; 104 \pm 58.0$ DIM). During a 4 -wk adaptation period, cows were housed in a freestall dairy barn in 2 separate treatment groups. The adaptation period served to introduce the experimental concentrates gradually into the diet.

After adaptation to the diet, cows were subjected to a 17-d experimental period. During this period, cows were housed in tie-stalls for $12 \mathrm{~d}$ and subsequently moved to respiration chambers for $5 \mathrm{~d}$. In the tie-stalls, animals were accustomed to be restricted in movement, and individual feed intake was measured. In the respiration chambers, gaseous exchange, individual feed intake, and feed digestibility were determined. The 17-d experimental period was replicated 4 times for each pair of animals with 24-d intervals between measurements to evaluate persistency of effects. During the $7 \mathrm{~d}$ that cows were not in the tie-stalls, they were housed in a freestall dairy barn, but were maintained in their treatment groups and fed their respective treatment diets. In this publication, $\mathrm{d} 1$ refers to the first day cows were housed in the tie-stalls. Only 2 respiration chambers were available for implementation of this experiment, which limited the number of animals that could be measured at the same time to 4 (2 on each treatment; 2 cows per chamber), and the groups of cows had to be allocated to the chambers in a staggered manner. Because of this allocation, the first group of cows completed the experiment after $89 \mathrm{~d}$ on the full nitrate diet, whereas the last group of cows had been on the full nitrate diet for $107 \mathrm{~d}$.

\section{Diets and Feeding}

Both diets consisted of $53 \%$ corn silage, $9 \%$ dried alfalfa, $4 \%$ barley straw, and $34 \%$ concentrates on a DM basis. The diets were offered as TMR and were prepared on a daily basis using a mixer wagon (Vertimix 500, Strautmann, Bad Laer, Germany). The concentrates for the urea and nitrate diets were balanced for $\mathrm{N}$ and $\mathrm{Ca}$ by the isonitrogenous exchange of urea for nitrate and the addition of limestone to the urea diet concentrate, respectively. Before the start of the adaptation period, the concentrate portion of the diet consisted of adaptation concentrates (Table 1). At the start of the adaptation period, $25 \%$ of the adaptation concentrates were replaced by 1 of the 2 experimental concentrates (urea or nitrate) for each treatment.

This ration was fed for $1 \mathrm{wk}$, after which the proportion of experimental concentrates was increased to $50 \%$ of the total amount of concentrates. Dietary proportions of experimental concentrates were increased by $25 \%$ in each additional week of the adaptation period, 
Table 1. Ingredient composition (\% of DM) of concentrates containing either urea or nitrate as NPN source

\begin{tabular}{lccc}
\hline Item & Adaptation & Urea & Nitrate \\
\hline Formaldehyde-treated soybean meal & - & 31.8 & 31.8 \\
Soybean meal & 51.3 & 0.0 & 0.0 \\
Wheat & 6.3 & 19.0 & 19.0 \\
Corn & 12.8 & 12.7 & 12.7 \\
Dried beet pulp & 20.1 & 13.3 & 13.3 \\
Fractionated palm oil & 3.7 & 7.3 & 7.3 \\
Trace mineral and vitamin premix & 2.2 & 2.2 & 2.2 \\
Monocalcium phosphate & 1.5 & 2.0 & 2.0 \\
MgSO$_{4}$ & - & 1.5 & 1.5 \\
NaCl & 0.7 & 1.5 & 1.5 \\
Urea & - & 3.5 & - \\
Wood cellulose & - & 0.3 & - \\
CaCO & - & 5.1 & - \\
Nitrate source & & & \\
${ }^{1}{ }_{5} \mathrm{Ca}\left(\mathrm{NO}_{3}\right)_{2} \cdot \mathrm{NH}_{4} \mathrm{NO}_{3} \cdot 10 \mathrm{H}_{2} \mathrm{O} ; 75 \% \mathrm{NO}_{3}$ in DM. & & &
\end{tabular}

until the concentrate proportion of the diets consisted fully of experimental concentrates after $3 \mathrm{wk}$. A fourth week was added to the adaptation period when the full amount of experimental concentrates was fed. The 4-wk period served to allow adaptation of the rumen microflora and to allow sufficient time for increased activity of bacterial nitrate and nitrite reductases (Alaboudi and Jones, 1985).

Cows were group-fed during the adaptation period. Cows were fed once daily during the period in the freestall barn (0900 h) and twice daily (0630 and $1630 \mathrm{~h}$; equal portions) during each 17-d experimental period. Water was freely available during the entire experiment.

In the tie-stalls and respiration chambers cows were individually fed. Orts were collected daily. Cows were fed ad libitum for the first $8 \mathrm{~d}$ of the experimental period and subsequently restricted in feed intake for the remainder of the 17-d experimental period. Within a block, feed intake was restricted to $95 \%$ of the ad libitum intake of the animal consuming the lowest amount of feed during d 5 to 8 . This approach was chosen to ensure similar feed intake between treatments, thus avoiding confounding effects of DMI on methane production.

\section{Sampling and Chemical Analysis}

Representative samples of TMR $( \pm 500 \mathrm{~g})$ were collected at each preparation of fresh TMR and stored frozen $\left(-20^{\circ} \mathrm{C}\right)$ pending analysis. Samples were thawed, pooled per period and treatment, subsampled $( \pm 500 \mathrm{~g})$, freeze-dried, and ground to pass a 1-mm screen before analysis. Individual roughage and concentrate samples were taken on d 10 of each period and stored frozen. After the experiment, corn silage, straw, and alfalfa samples were analyzed by near infrared spectroscopy
(Blgg, Oosterbeek, the Netherlands). Samples of dried alfalfa and straw were pooled by roughage type over the entire experiment and subsampled before analysis (1 sample for each roughage type); corn silage samples were analyzed individually per measuring period. The total production of feces and urine was collected after completion of each measurement period, mixed thoroughly, and subsampled for analysis. Dry matter, CP, crude fat, sugar, starch, and NDF content of TMR, concentrate, and manure samples were determined according to the methods described in detail in Abrahamse et al. (2008). Gross energy (GE) content was determined using bomb calorimetry (IKA-C700, Janke \& Kunkel, Heitersheim, Germany). Nitrate was determined as described previously by van Zijderveld et al. (2010).

\section{Gaseous Exchange and Diet Digestibility}

The respiration indirect calorimetric chambers used in this study have been described in detail by Verstegen et al. (1987). Measurements of gaseous exchange and diet digestibility were performed as described previously by van Zijderveld et al. (2011). Heat production was calculated according to the methods of Brouwer (1965). Cows were housed in pairs on the same treatment in the respiration chambers.

\section{Determination of Hydrogen Production}

Hydrogen production was determined in period 4 of this experiment between 0630 and $1530 \mathrm{~h}$. Air samples were taken manually from the in- and outgoing air from the respiration chambers by means of a syringe (2-3 samples/h). The syringe was injected into a gas chromatograph (Quintron Breathtracker DP, Quintron Instrument Company, Milwaukee, WI) within approxi- 
mately 10 min after the sample was taken. Hydrogen production was subsequently calculated by multiplication of the $\mathrm{H}_{2}$ concentrations by the measured airflow rate through the chambers.

\section{Milk Yield and Composition}

Cows were milked twice daily during the entire experiment (0630 and $1630 \mathrm{~h}$ ). Milk yield was determined daily. In the respiration chamber, milk was sampled during each milking and stored in a refrigerator at $4^{\circ} \mathrm{C}$ in tubes containing sodium azide. These samples were analyzed for fat, CP, lactose, urea, and SCC as described previously by van Zijderveld et al. (2011) at the end of each experimental period. Average milk component concentrations during the measurement period were calculated from the weighted average of all samples taken. At each milking, additional samples (3 $\mathrm{g} / \mathrm{kg}$ of milk) were taken for GE determination.

\section{Blood Sampling}

In the respiration chambers, blood was sampled on the third day of each measurement period. Blood was sampled from the tail vein at $3 \mathrm{~h}$ postfeeding in heparinized collection tubes (Becton Dickinson, Breda, the Netherlands). Blood was analyzed for hemoglobin (Hb) and methemoglobin (MetHb) contents within $1 \mathrm{~h}$ after collection with a hemoximeter (OSM 3, Radiometer, Copenhagen, Denmark).

\section{Statistical Analyses}

Data collected during the measurement period only were used for statistical analyses. Data on gaseous emissions from the last $72 \mathrm{~h}$ of each measurement period were averaged per period before analysis. Data measured on individual animals (milk production, milk composition, blood parameters, and DMI) were subjected to repeated-measures ANOVA including block and treatment as fixed factors. Data collected during the 4 experimental periods were treated as repeated measures per animal or pair of animals. Data collected on pairs of cows (gaseous exchange and diet digestibility parameters) were subjected to repeated-measures ANOVA with treatment as fixed factor. Significance of effects was declared at $P<0.05$. The statistical program Genstat (11th ed., Lawes Agricultural Trust, Rothamsted, UK) was used to analyze the data.

\section{RESULTS}

\section{Diet Composition}

Chemical composition of dietary concentrates was established as formulated (Table 2); complete diets were isoenergetic (on a GE basis) and isonitrogenous.

\section{Animal Performance and Methane Production}

Methane production was reduced by $16 \%$ on the nitrate diet (Table 3 ) when expressed on a daily basis, as grams per kilogram of DMI or as percentage of gross energy intake (GEI). When expressed per kilogram of milk, methane was decreased by $14 \%$. Daily methane production increased with time during the experiment for both treatments. No significant interaction was observed between treatment and time.

Dry matter intake was not affected by treatment, but increased with time for both treatments. Milk yield was unaffected by treatment, but decreased in time as cows advanced in lactation. Protein content of milk was lower for the nitrate diet (3.21 vs. $3.05 \pm 0.058 \%$, urea vs. nitrate respectively), but milk protein yield was unaffected by treatment. Other milk constituents were unaffected by treatment or time.

Table 2. Analyzed chemical composition of TMR ingredients and complete TMR containing either a urea or nitrate source

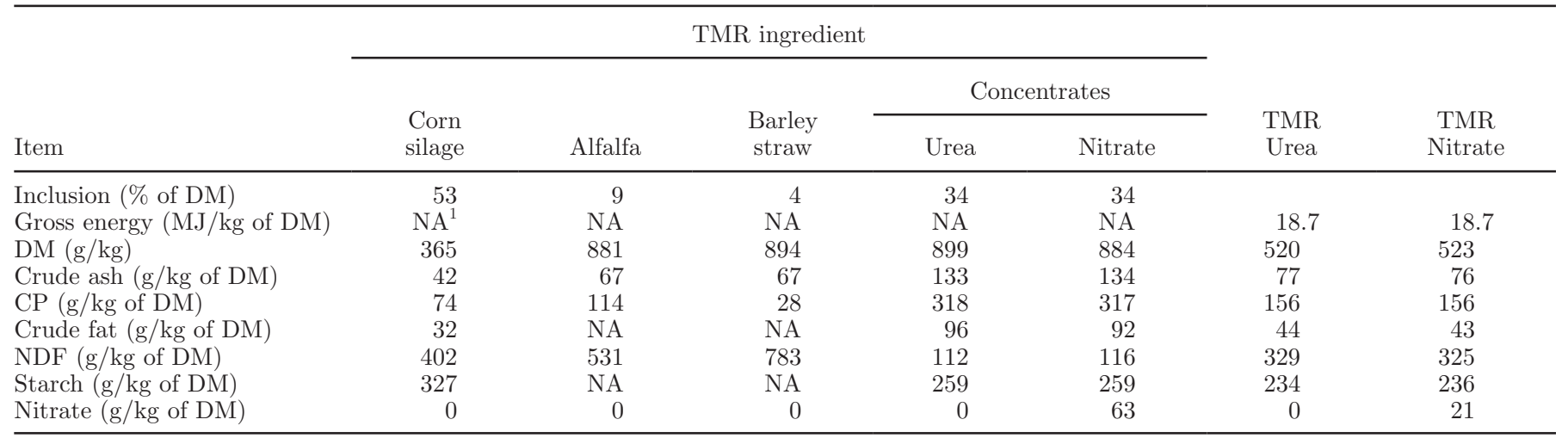

${ }^{1} \mathrm{NA}=$ not analyzed. 


\section{Energy Balance, Nitrogen Balance, and Digestibility}

Gross energy intake was not affected by treatment, but increased as the experiment progressed (Table 4). Energy lost in methane production was lower for the nitrate diet and increased during the experiment for both treatments. The energy lost in urine and feces and ME intake (MEI) were unaffected by treatment. Although MEI was not affected by treatment, the MEI:GEI ratio was elevated as a consequence of nitrate feeding ( 57.3 vs. $58.6 \pm 0.70 \%$, urea vs. nitrate, respectively). Calculated heat production was unaffected by treatment, but increased over time. Milk energy yield was unaffected by treatment or time. Despite the higher MEI:GEI ratio, energy retention (ER) was not increased for the nitrate treatment. Apparent total-tract digestibility of NDF, starch, and crude fat were unaffected by treatment.

Nitrogen balance (Table 5) was mostly positive for both treatments and no differences between treatments were observed. Nitrogen intake increased as the experiment progressed. The conversion efficiency of feed $\mathrm{N}$ into milk $\mathrm{N}$ was not affected by treatment but decreased with time for both treatments.

\section{Hydrogen Production}

Cumulative hydrogen production was higher for the nitrate diet during the 9-h measurement period in experimental period $4(1.9 \mathrm{~L} /$ cow per $9 \mathrm{~h}$ for urea vs. $5.8 \mathrm{~L} /$ cow per $9 \mathrm{~h}$ for nitrate; $P=0.003$ ). Hydrogen production was higher up to $7 \mathrm{~h}$ after feeding for the nitrate diet (Figure 1). The variability in hydrogen production was much larger for pairs of animals on the nitrate treatment than for those on the urea treatment. Methane production was suppressed for a period of $5 \mathrm{~h}$ after feeding with nitrate, and this depression in methane production largely coincided with the increase in hydrogen production for this treatment.

\section{Blood Parameters}

Methemoglobin content of blood was consistently higher for cows on the nitrate diet (Table 6) and was not affected by time on treatment. Hemoglobin content was lower for the nitrate-fed animals and increased with time for both treatments.

\section{DISCUSSION}

\section{Methane Abatement by Dietary Nitrate}

In this research, we demonstrated for the first time that nitrate decreases methane production persistently

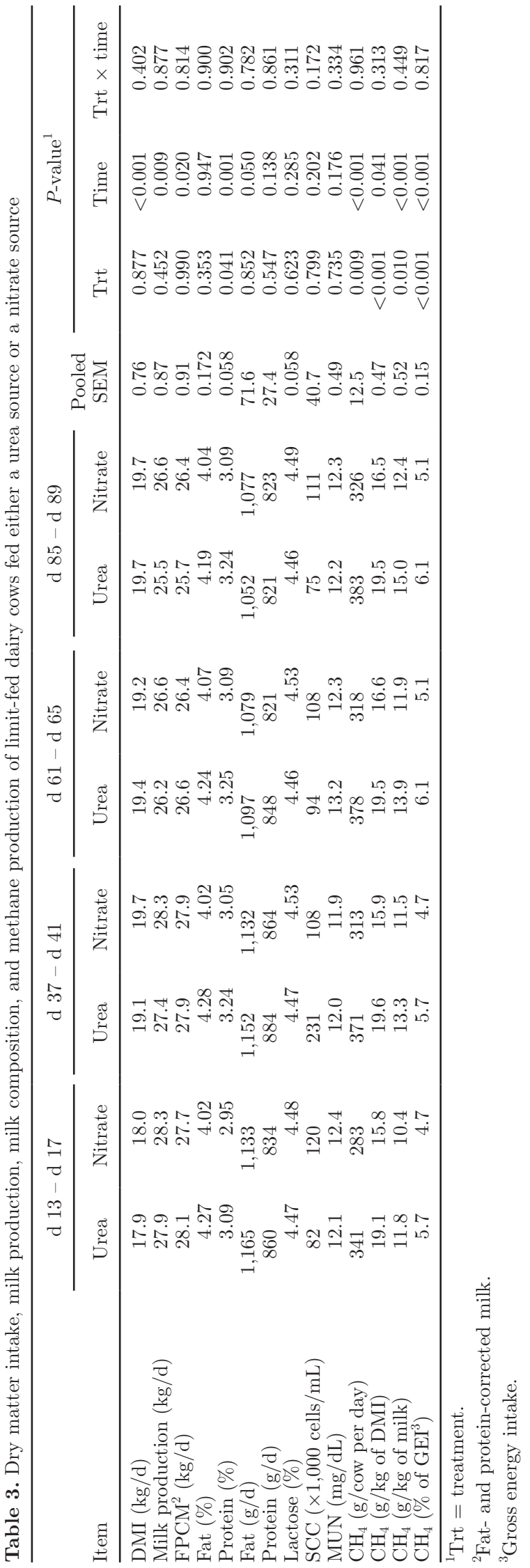


Table 4. Energy balance and apparent total-tract diet digestibility of limit-fed dairy cows fed either a urea source or a nitrate source

\begin{tabular}{|c|c|c|c|c|c|c|c|c|c|c|c|c|}
\hline \multirow[b]{2}{*}{ Item } & \multicolumn{2}{|c|}{ d $13-$ d 17} & \multicolumn{2}{|c|}{ d $37-$ d 41} & \multicolumn{2}{|c|}{ d $61-$ d 65} & \multicolumn{2}{|c|}{ d $85-$ d 89} & \multirow[b]{2}{*}{$\begin{array}{c}\text { Pooled } \\
\text { SEM }\end{array}$} & \multicolumn{3}{|c|}{$P$-value ${ }^{1}$} \\
\hline & Urea & Nitrate & Urea & Nitrate & Urea & Nitrate & Urea & Nitrate & & Trt & Time & $\begin{array}{c}\text { Trt } \times \\
\text { time }\end{array}$ \\
\hline Metabolic BW (kg/cow) & 117 & 120 & 118 & 121 & 122 & 118 & 121 & 122 & 3.2 & 0.912 & 0.273 & 0.132 \\
\hline $\mathrm{GEI}^{2}\left(\mathrm{~kJ} / \mathrm{kg}\right.$ of $\mathrm{BW}^{0.75}$ per day $)$ & 2,831 & 2,789 & 3,033 & 3,060 & 2,834 & 2,930 & 2,904 & 2,887 & 75.5 & 0.863 & 0.002 & 0.433 \\
\hline Energy feces + urine $\left(\mathrm{kJ} / \mathrm{kg}\right.$ of $\mathrm{BW}^{0.75}$ per day $)$ & 1,023 & 1,012 & 1,108 & 1,112 & 1,086 & 1,077 & 1,058 & 1,053 & 35.2 & 0.904 & 0.003 & 0.983 \\
\hline Methane production $\left(\mathrm{kJ} / \mathrm{kg}\right.$ of $\mathrm{BW}^{0.75}$ per day) & 161 & 131 & 174 & 143 & 172 & 149 & 176 & 148 & 5.0 & 0.002 & $<0.001$ & 0.425 \\
\hline $\mathrm{MEI}^{3}\left(\mathrm{~kJ} / \mathrm{kg}\right.$ of $\mathrm{BW}^{0.75}$ per day $)$ & 1,647 & 1,645 & 1,750 & 1,805 & 1,577 & 1,704 & 1,670 & 1,686 & 49.0 & 0.375 & 0.015 & 0.332 \\
\hline MEI:GEI ratio (\%) & 58.2 & 59.0 & 57.7 & 59.0 & 55.6 & 58.2 & 57.5 & 58.3 & 0.70 & 0.036 & 0.118 & 0.498 \\
\hline Heat production $\left(\mathrm{kJ} / \mathrm{kg}\right.$ of $\mathrm{BW}^{0.75}$ per day) & 951 & 962 & 989 & 998 & 975 & 987 & 987 & 991 & 17.9 & 0.713 & $<0.001$ & 0.929 \\
\hline Energy in milk $\left(\mathrm{kJ} / \mathrm{kg}\right.$ of $\mathrm{BW}^{0.75}$ per day $)$ & 704 & 710 & 702 & 700 & 715 & 691 & 656 & 697 & 18.1 & 0.699 & 0.269 & 0.290 \\
\hline $\mathrm{ER}^{4}$ total $\left(\mathrm{kJ} / \mathrm{kg}\right.$ of $\mathrm{BW}^{0.75}$ per day $)$ & -9 & -27 & 60 & 107 & -114 & 26 & 29 & -3 & 49.9 & 0.433 & 0.105 & 0.275 \\
\hline ER protein ${ }^{4}\left(\mathrm{~kJ} / \mathrm{kg}\right.$ of $\mathrm{BW}^{0.75}$ per day $)$ & 0 & 22 & 8 & 17 & 11 & 22 & 28 & 33 & 11.6 & 0.247 & 0.287 & 0.799 \\
\hline ER fat ${ }^{4}\left(\mathrm{~kJ} / \mathrm{kg}\right.$ of $\mathrm{BW}^{0.75}$ per day $)$ & -9 & -48 & 52 & 90 & -124 & 4 & 1 & -36 & 43.1 & 0.558 & 0.051 & 0.180 \\
\hline NDF digestibility (\%) & 52.1 & 52.7 & 52.6 & 53.9 & 52.1 & 53.9 & 53.3 & 52.7 & 1.09 & 0.364 & 0.846 & 0.672 \\
\hline Starch digestibility (\%) & 97.3 & 96.6 & 98.0 & 98.5 & 97.5 & 98.7 & 98.4 & 98.5 & 0.28 & 0.217 & 0.002 & 0.053 \\
\hline Fat digestibility (\%) & 70.2 & 71.8 & 60.4 & 66.3 & 63.1 & 57.9 & 64.8 & 59.6 & 3.19 & 0.791 & 0.027 & 0.217 \\
\hline
\end{tabular}

${ }^{2} \mathrm{GEI}=$ gross energy intake.

${ }^{3} \mathrm{MEI}=\mathrm{ME}$ intake; $\mathrm{MEI}=\mathrm{GEI}-$ energy feces + urine - methane production.

${ }^{4} \mathrm{ER}=$ energy retention. ER total $=\mathrm{MEI}-$ heat production - energy in milk; ER protein $=$ protein gain $\times 23.6 \mathrm{~kJ} / \mathrm{g}$ of protein; ER fat $=\mathrm{ER}$ total $-\mathrm{ER}$ protein.

Table 5. Nitrogen balance $\left(\mathrm{mg} / \mathrm{kg}\right.$ of $\mathrm{BW}^{0.75}$ per day) and $\mathrm{N}$ efficiency (\%) of limit-fed dairy cows fed either a urea source or a nitrate source

\begin{tabular}{|c|c|c|c|c|c|c|c|c|c|c|c|c|}
\hline \multirow[b]{2}{*}{ Item } & \multicolumn{2}{|c|}{ d $13-$ d 17} & \multicolumn{2}{|c|}{ d $37-\mathrm{d} 41$} & \multicolumn{2}{|c|}{ d $61-$ d 65} & \multicolumn{2}{|c|}{ d $85-$ d 89} & \multirow{2}{*}{$\begin{array}{l}\text { Pooled } \\
\text { SEM }\end{array}$} & \multicolumn{3}{|c|}{$P$-value ${ }^{1}$} \\
\hline & Urea & Nitrate & Urea & Nitrate & Urea & Nitrate & Urea & Nitrate & & Trt & Time & Trt $\times$ time \\
\hline $\mathrm{N}$ intake & 3,814 & 3,829 & 3,974 & 4,037 & 4,032 & 3,981 & 4,050 & 4,064 & 103.2 & 0.935 & 0.024 & 0.819 \\
\hline $\mathrm{N}$ urine + feces & 2,573 & 2,509 & 2,707 & 2,734 & 2,746 & 2,680 & 2,749 & 2,680 & 80.2 & 0.660 & 0.009 & 0.729 \\
\hline $\mathrm{N}$ milk & 1,148 & 1,080 & 1,154 & 1,122 & 1,145 & 1,078 & 1,052 & 1,091 & 28 & 0.107 & 0.189 & 0.242 \\
\hline $\mathrm{N}$ condens ${ }^{2}$ & 92 & 95 & 60 & 66 & 70 & 74 & 61 & 65 & 21.6 & 0.794 & 0.360 & 0.978 \\
\hline $\mathrm{N}$ balance & 1 & 146 & 53 & 114 & 72 & 149 & 189 & 226 & 78.7 & 0.247 & 0.287 & 0.799 \\
\hline $\mathrm{N}$ efficiency ( $\mathrm{N}$ milk/ $\mathrm{N}$ feed) & 30.8 & 28.9 & 29.6 & 28.5 & 29.2 & 27.7 & 26.6 & 27.4 & 0.98 & 0.267 & 0.073 & 0.450 \\
\hline $\begin{array}{l}{ }^{1} \mathrm{Trt}=\text { treatment. } \\
{ }^{2} \mathrm{~N} \text { in condensate that was coll }\end{array}$ & & & & & & & & & & & & \\
\hline
\end{tabular}




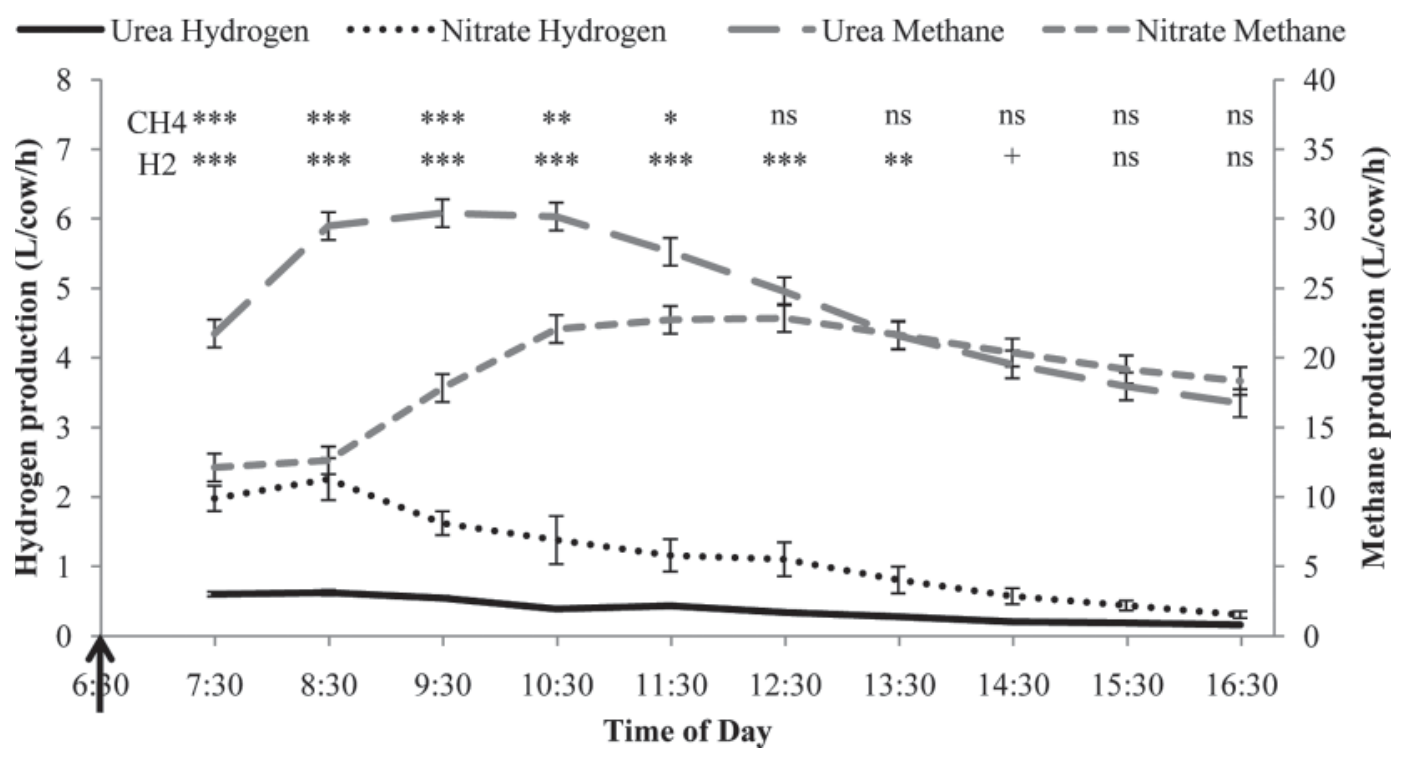

Figure 1. Ruminal hydrogen and methane production over a 9-h period from lactating dairy cows fed either a urea or a nitrate source. Data represent mean values obtained during experimental period 4 of the main experiment. Error bars indicate SEM. Arrow indicates time of feeding. Symbols indicate whether the treatment effect was significant for the respective time point: $* * * P<0.001 ;{ }^{* *} P<0.01 ; * P<0.05 ;+P<0.10$; ns $=$ not significant.

in dairy cows. The methane decrease confirms earlier observations in nitrate-fed sheep (Nolan et al., 2010; van Zijderveld et al., 2010) or sheep ruminally infused with nitrate solutions (Takahashi and Young, 1991; Sar et al., 2004). We hypothesized that reduction of nitrate to nitrite and then ammonia would provide a sink for metabolic hydrogen, thus decreasing its availability for methanogenesis. Nitrate reduction is energetically more favorable than methanogenesis (Ungerfeld and Kohn, 2006). Cows in this experiment consumed, on average, $21 \mathrm{~g}$ of nitrate/ $\mathrm{kg}$ of DM. Complete reduction of this nitrate to ammonia would consume sufficient hydrogen to decrease methane emissions by $5.4 \mathrm{~g}$ of methane $/ \mathrm{kg}$ of DM (25.8 g of $\mathrm{CH}_{4}$ reduction/100 g of nitrate fed; van Zijderveld et al., 2010). The decrease in methane production was only $3.2 \mathrm{~g}$ of methane $/ \mathrm{kg}$ of DM or $59 \%$ of this theoretical potential. This could indicate that nitrate was not fully reduced to ammonia, using only part of the theoretical amount of hydrogen required compared with a situation in which full reduction would have occurred. Considering that hydrogen losses also increased with the nitrate diet, the actual efficiency of nitrate reduction in abating methanogenesis would be even lower.

Cows in both treatment groups were fed a diet containing $156 \mathrm{~g}$ of $\mathrm{CP} / \mathrm{kg}$ of DM. Twenty-two percent of this CP consisted of NPN, originating from either urea or nitrate. Rumen microbes require a minimum level of rumen ammonia to maintain optimal growth conditions (Dijkstra et al., 1998). If $44 \%$ of the nitrate would not have been reduced to ammonia, this would theoretically have lowered the available $\mathrm{CP}$ content of the nitrate diet by $15 \mathrm{~g} / \mathrm{kg}$ of DM, mainly limiting availability of rumen-available N. When calculated according to the Dutch protein evaluation (DVE) system, the decreased availability of $\mathrm{N}$ from nitrate would have resulted in a negative rumen available $\mathrm{N}$ balance, which could be expected to have a negative effect on microbial protein synthesis and dairy cow productivity. Milk CP concentration was lower for the nitrate diet; however, daily milk protein production was unaffected by treatment and the lower protein concentration may have been a consequence of dilution. In addition, the efficiency with which $\mathrm{N}$ was used for milk protein synthesis was unaffected by treatment. Moreover, MUN did not differ between treatments; if ammonia levels in the rumen were lower because of incomplete reduction of nitrate, this probably would have been reflected in decreased MUN levels (Gustafsson and Palmquist, 1993). It therefore seems unlikely that incomplete nitrate reduction was responsible for the lower relative effectiveness of nitrate in dairy cows.

Methanogenesis is not the only sink for hydrogen in the rumen. Hydrogen is also used for the production of the more reduced acids propionate and valerate (Czerkawski, 1972), and increases in molar proportions of propionate in rumen fluid are negatively associated with methanogenesis (Ellis et al., 2008; Janssen, 2010). Nitrate reduction is thermodynamically more favorable than propionogenesis (Ungerfeld and Kohn, 2006) and 
may successfully compete for hydrogen with propionogenesis. This would mean that nitrate reduction draws electrons from both methanogenesis and propionogenesis. Indeed, it has been demonstrated that feeding nitrate at $2 \%$ of $\mathrm{DM}$ to dairy cows increases the molar proportion of acetate, at the expense of propionate and butyrate (Farra and Satter, 1971), and such a shift will decrease the amount of hydrogen consumed in propionogenesis (Ellis et al., 2008). The efficacy of nitrate as a methane inhibitor may therefore depend on the relative importance of propionogenesis in the host animal.

In sheep, the apparent efficiency of nitrate use in methane mitigation was much higher $(78 \%$, Nolan et al., 2010; 89\%, van Zijderveld et al., 2010) than in cattle in the present experiment (59\%). Sheep have a much lower feed intake relative to their body weight and a higher rumen $\mathrm{pH}$; in that situation, relatively less propionic acid and more acetic acid and butyric acid are produced (Bannink et al., 2008). Therefore, propionogenesis might play a smaller role in sheep compared with lactating cows and nitrate reduction might obtain more of its reducing equivalents in competition with propionogenesis in dairy cows and more in competition with methanogenesis in sheep. This would imply that nitrate is more effective in decreasing methane emissions in animals fed near maintenance, with a relatively minor role for propionogenesis.

It is likely that part of the ingested nitrate and part of the nitrite formed in the rumen were absorbed through the rumen wall into the blood and subsequently lost in urine (Takahashi et al., 1998) and thus unavailable for reduction to ammonia in the rumen. Clearance of nitrate and nitrite to blood might therefore be an additional explanation for the lower than expected inhibition of methanogenesis. In previous studies with sheep (Nolan et al., 2010; van Zijderveld et al., 2010), the dietary inclusion of nitrate was higher than that in the current study (24 and $26 \mathrm{~g}$ of nitrate $/ \mathrm{kg}$ of DM in the respective sheep studies compared with $21 \mathrm{~g}$ of nitrate/kg of DM in the current study). However, when expressed relative to metabolic $\mathrm{BW}$, the nitrate dose in the current experiment was considerably higher than in our previous study with sheep $(3.4 \mathrm{~g}$ of nitrate $/ \mathrm{kg}$ of $\mathrm{BW}^{0.75}$ per day vs. $1.6 \mathrm{~g}$ of nitrate $/ \mathrm{kg}$ of $\mathrm{BW}^{0.75}$ per day for dairy cows and sheep, respectively). This higher dose may have led to a higher proportion of the dietary nitrate entering the blood through the rumen wall and being lost in urine. This could be another explanation for the relatively higher efficiency of methane abatement with dietary nitrate in sheep.

Cows on the nitrate diet had elevated blood MetHb levels. This indicates that a pool of nitrite, absorbed from the rumen, was present in the blood. In sheep studies (Nolan et al., 2010; van Zijderveld et al., 2010), 
no significant elevations of MetHb were observed when similar levels of dietary nitrate on diet DM basis were fed. This supports the above-mentioned hypothesis that larger amounts of nitrate and nitrite are transferred from the rumen to the blood when higher doses, expressed per kilogram of metabolic weight, are fed.

Methane is a loss of dietary energy for the dairy cow (Johnson and Johnson, 1995), and the capture of lost hydrogen may be a way to enhance the energetic efficiency of the cow. In our experiment, the reducing equivalents that would normally have been lost in methane production are assumed to have been taken up during nitrate reduction to ammonia. This might have benefited animal productivity if ruminal ammonia concentrations had been limiting animal production. This is unlikely, however; dietary CP levels were adequate on both treatments, and MUN levels suggest that dietary $\mathrm{N}$ was not limiting productivity. Moreover, nitrate reduction may have even drawn reducing equivalents away from propionogenesis in our experiment. Propionate may be a nutrient limiting animal productivity (Huhtanen et al., 1998) and the redirection of reducing equivalents into ammonia rather than propionate may even be more limiting to animal productivity. In the present experiment, although methane production was decreased and the ratio of MEI to GEI increased, energy in milk or energy retention was not affected by nitrate supplementation.

\section{Occurrence of Methemoglobinemia}

Methemoglobinemia occurs when nitrite is absorbed from the rumen into the blood of the animal. Ferrous iron $\left(\mathrm{Fe}^{2+}\right)$ in hemoglobin is transformed into ferric iron $\left(\mathrm{Fe}^{3+}\right)$, rendering the hemoglobin molecule (now called methemoglobin) incapable of transporting oxygen to the tissues (Ozmen et al., 2005). Nitrite is formed in the rumen as an intermediate in the reduction of nitrate to ammonia. In animals not previously adapted to nitrate in their diet, the reduction of nitrate to nitrite occurs at a higher rate than the reduction of nitrite to ammonia, resulting in an accumulation of nitrite in the rumen and subsequent absorption (Bruning-Fann and Kaneene, 1993). Adapting animals slowly to nitrate in their diet enables the population of nitrite-reducing bacteria to increase in size, increasing the capacity to reduce nitrite (Allison and Reddy, 1984). An adaptation period has been demonstrated to enable ruminants to cope with higher levels of nitrate in their diets (Alaboudi and Jones, 1985; van Zijderveld et al., 2010). In our study, an adaptation period to dietary nitrate was included, but MetHb levels were still higher $(P=0.008$; Table 6 ) for the nitrate-fed cows. It has been proposed that animals respond to prolonged elevated MetHb lev- els in their blood by producing more $\mathrm{Hb}$, thereby compensating for the decreased oxygen-carrying capacity of the blood (Winter and Hokanson, 1964). No evidence of such a mechanism was observed in this study. Although average MetHb levels were no reason for concern on the nitrate diet, peak levels for individual animals were 4- to 5-fold the average level in the cows on the urea diet, but still below the level considered to cause subclinical methemoglobinemia (30-40\%; Bruning-Fann and Kaneene, 1993).

\section{Yield of Usable ME as a Consequence of Methane Reduction}

If GEI and digestibility are not altered, a decrease in methane production will increase the amount of $\mathrm{ME}$ available to the animal, which could increase milk production or body tissue gain (Blaxter and Czerkawski, 1966). In this experiment, methane production was lowered $\left(-28 \mathrm{~kJ} / \mathrm{kg}\right.$ of $\mathrm{BW}^{0.75}$ per day or $\left.3.4 \mathrm{MJ} / \mathrm{d}\right)$ and apparent NDF, crude fat, and starch digestibility were unaffected by treatment. The conversion of GE into ME was also improved for the nitrate diet. If the energy spared from methanogenesis had been fully converted into milk with an efficiency of 0.64 (NRC, 2001), the increase in milk yield would have been 0.7 $\mathrm{kg}$ (milk energy was $3.1 \mathrm{MJ} / \mathrm{kg}$ for this experiment). However, no significant increase in milk energy output was observed in this experiment, although milk energy output was numerically higher for the nitrate diet $(+6$ $\mathrm{kJ} / \mathrm{kg} \mathrm{BW}{ }^{0.75}$ per day or $0.7 \mathrm{MJ} / \mathrm{d}$ ). The majority of the energy saved from decreased methane production appeared to accumulate in the calculated energy retention, which increased nonsignificantly for the nitrate $\operatorname{diet}\left(+34 \mathrm{~kJ} / \mathrm{kg} \mathrm{BW}{ }^{0.75}\right.$ per day or $\left.4.1 \mathrm{MJ} / \mathrm{d}\right)$. Despite the significant reduction in methane production, no positive responses in animal performance parameters were observed.

During experimental period 4, hydrogen production was measured and was found to be higher for the nitrate diet. Our hypothesis was that nitrate would act as a hydrogen sink and the reason for the elevated hydrogen emissions for the nitrate diet is unknown. Hydrogen is an energy-dense gas and its emission by the animal could offset the energy benefit gained by the decrease in methane production. In experimental period 4, hydrogen production was measured from 0630 to $1530 \mathrm{~h}$. The average hydrogen production over this 9-h period was $1.9 \mathrm{~L} /$ cow for the urea diet and $5.8 \mathrm{~L} /$ cow for the nitrate diet. If results from the 9-h period are extrapolated to a 24 -h period, hydrogen production is estimated to amount to $5 \mathrm{~L} /$ cow per day for the urea diet and $15 \mathrm{~L} /$ cow per day for the nitrate diet. The additional $10 \mathrm{~L} / \mathrm{d}$ of hydrogen produced for the nitrate 
diet translate into $0.45 \mathrm{~mol}$ of hydrogen/d $(22.4 \mathrm{~L} /$ $\mathrm{mol}$ ) or $0.9 \mathrm{~g}$ of hydrogen/d. Hydrogen is energy dense $\left(142 \mathrm{~kJ} / \mathrm{g}\right.$ of $\mathrm{H}_{2}$ : Afeefy et al. (2011), but the additional energy lost in hydrogen production for the nitrate diet was calculated to be relatively minor (approximately $1.0 \mathrm{~kJ} / \mathrm{kg} \mathrm{BW}{ }^{0.75}$ per day or $3.6 \%$ of the observed methane decrease).

The simple statement that decreasing enteric methane emissions without affecting feed digestibility will increase the animals' productivity or energy retention therefore appears to be inadequate. A further requirement would be that the reducing equivalents spared from methane production are incorporated in molecules that are limiting either bacterial or animal metabolic processes. The direct environmental impact of methane production from the dairy cows in this experiment was decreased; daily methane production was lowered by 58 $\mathrm{g} /$ cow per day, or $1.5 \mathrm{~kg}$ of $\mathrm{CO}_{2}$-equivalents/cow per day.

\section{CONCLUSIONS}

Nitrate addition to corn silage-based dairy cow diets for $89 \mathrm{~d}$ persistently decreased enteric methane emissions by $16 \%$ without negatively affecting diet digestibility and milk production. The energetic benefit from the decreased methane production did not appear to benefit the animal, as milk production and energy balance were not affected.

\section{ACKNOWLEDGMENTS}

Alessandro Bisesti, Sven Alferink, Tamme Zandstra, Marcel Heetkamp, Ries Verkerk, Ilona van den Anker, Saskia van Laar, Willem van Ommeren, and Bert Beukers of Wageningen University (Wageningen, the Netherlands) and Geronda Klop and Peter Jansen of the University of Applied Sciences HAS Den Bosch (Den Bosch, the Netherlands) are acknowledged for their skilled assistance during the implementation of the experiments. These studies were partially funded by SenterNovem, an agency of the Dutch Ministry of Economical Affairs.

\section{REFERENCES}

Abrahamse, P. A., J. Dijkstra, B. Vlaeminck, and S. Tamminga. 2008. Frequent allocation of rotationally grazed dairy cows changes grazing behavior and improves productivity. J. Dairy Sci. 91:20332045.

Afeefy, H. Y., J. F. Liebman, and S. E. Stein. 2011. Neutral thermochemical data. NIST Chemistry WebBook, NIST Standard Reference Database Number 69. Vol. 2011. P. J. Linstrom and W. G. Mallard, ed. National Institute of Standards and Technology, Gaithersburg, MD.

Alaboudi, A. R., and G. A. Jones. 1985. Effect of acclimation to high nitrate intakes on some rumen fermentation parameters in sheep. Can. J. Anim. Sci. 65:841-849.
Allison, M. J., and C. A. Reddy. 1984. Adaptations of gastrointestinal bacteria in response to changes in dietary oxalate and nitrate. Pages 248-256 in Third Int. Symp. Microbial Ecology. K. M. J. and C. A. Reddy, ed. American Society of Microbiology, Washington, DC.

Bannink, A., J. France, S. Lopez, W. J. J. Gerrits, E. Kebreab, S. Tamminga, and J. Dijkstra. 2008. Modelling the implications of feeding strategy on rumen fermentation and functioning of the rumen wall. Anim. Feed Sci. Technol. 143:3-26.

Blaxter, K. L., and J. Czerkawski. 1966. Modification of the methane production of the sheep by supplementation of its diet. J. Sci. Food Agric. 17:417-421.

Brouwer, E. 1965. Page 441 in Energy Metabolism. K. L. Blaxter, ed. Academic Press, London, UK.

Bruning-Fann, C. S., and J. B. Kaneene. 1993. The effects of nitrate, nitrite, and n-nitroso compounds on animal health. Vet. Hum. Toxicol. 35:237-253.

Czerkawski, J. W. 1972. Fate of metabolic hydrogen in the rumen. Proc. Nutr. Soc. 31:141-146.

Dijkstra, J., J. France, and D. R. Davies. 1998. Different mathematical approaches to estimating microbial protein supply in ruminants. J. Dairy Sci. 81:3370-3384.

Ellis, J. L., J. Dijkstra, E. Kebreab, A. Bannink, N. E. Odongo, B. W. McBride, and J. France. 2008. Aspects of rumen microbiology central to mechanistic modelling of methane production in cattle. J. Agric. Sci. 146:213-233.

FAO. 2010. Greenhouse Gas Emissions from the Dairy Sector: A Life Cycle Assessment. Food and Agriculture Organization, Rome, Italy.

Farra, P. A., and L. D. Satter. 1971. Manipulation of the ruminal fermentation. II. Effect of nitrate on ruminal volatile fatty acid production and milk composition. J. Dairy Sci. 54:1018-1024.

Gustafsson, A. H., and D. L. Palmquist. 1993. Diurnal variation of rumen ammonia, serum urea, and milk urea in dairy cows at high and low yields. J. Dairy Sci. 76:475-484.

Huhtanen, P. J., R. Blauwiekel, and I. Saastamoinen. 1998. Effects of intraruminal infusions of propionate and butyrate with two different protein supplements on milk production and blood metabolites in dairy cows receiving grass silage-based diet. J. Sci. Food Agric. $77: 213-222$

Janssen, P. H. 2010. Influence of hydrogen on rumen methane formation and fermentation balances through microbial growth kinetics and fermentation thermodynamics. Anim. Feed Sci. Technol. 160:1-22.

Johnson, K. A., and D. E. Johnson. 1995. Methane emissions from cattle. J. Anim. Sci. 73:2483-2492.

Martin, C., D. P. Morgavi, and M. Doreau. 2010. Methane mitigation in ruminants: From microbe to the farm scale. Animal 4:351-365.

Nolan, J. V., R. S. Hegarty, J. Hegarty, I. R. Godwin, and R. Woodgate. 2010. Effects of dietary nitrate on fermentation, methane production and digesta kinetics in sheep. Anim. Prod. Sci. 50:801-806.

NRC. 2001. Nutrient Requirements of Cattle. 7th rev. ed. National Academy Press, Washington, DC.

Ozmen, O., F. Mor, S. Sahinduran, and A. Unsal. 2005. Pathological and toxicological investigations of chronic nitrate poisoning in cattle. Toxicol. Environ. Chem. 87:99-106.

Sar, C., B. Santoso, B. Mwenya, Y. Gamo, T. Kobayashi, R. Morikawa, K. Kimura, H. Mizukoshi, and J. Takahashi. 2004. Manipulation of rumen methanogenesis by the combination of nitrate with [beta] 1-4 galacto-oligosaccharides or nisin in sheep. Anim. Feed Sci. Technol. 115:129-142.

Takahashi, J., M. Ikeda, S. Matsuoka, and H. Fujita. 1998. Prophylactic effect of L-cysteine to acute and subclinical nitrate toxicity in sheep. Anim. Feed Sci. Technol. 74:273-280.

Takahashi, J., and B. A. Young. 1991. Prophylactic effect of cysteine on nitrate-induced alterations in respiratory exchange and metabolic rate in sheep. Anim. Feed Sci. Technol. 35:105-113.

Ungerfeld, E. M., and R. A. Kohn. 2006. The role of thermodynamics in the control of ruminal fermentation. Pages 55-85 in Ruminant Physiology: Digestion, Metabolism and Impact of Nutrition on Gene Expression, Immunology and Stress. K. Sejrsen, T. Hvel- 
plund, and M. O. Nielsen, ed. Wageningen Academic Publishers, Wageningen, the Netherlands.

van Zijderveld, S. M., B. Fonken, J. Dijkstra, W. J. J. Gerrits, H. B. Perdok, W. Fokkink, and J. R. Newbold. 2011. Effects of a combination of feed additives on methane production, diet digestibility, and animal performance in lactating dairy cows. J. Dairy Sci. 94:1445-1454.

van Zijderveld, S. M., W. J. J. Gerrits, J. A. Apajalahti, J. R. Newbold, J. Dijkstra, R. A. Leng, and H. B. Perdok. 2010. Nitrate and sulfate: Effective alternative hydrogen sinks for mitigation of ruminal methane production in sheep. J. Dairy Sci. 93:5856-5866.

Verstegen, M. W. A., W. Van der Hel, H. A. Brandsma, A. M. Henken, and A. M. Bransen. 1987. The Wageningen respiration unit for animal production research: A description of the equipment and its possibilities. Pages 21-48 in Energy Metabolism in Farm Animals:
Effects of Housing, Stress and Disease. Martinus Nijhoff Publishers, Dordrecht, the Netherlands.

Williams, A. G., E. Audsley, and D. L. Sandars. 2008. Environmental burdens of livestock production systems derived from life cycle assessment (lca). Pages 171-200 in Recent Advances in Animal Nutrition. P. C. Garnsworthy and J. Wiseman, ed. Nottingham University Press, Nottingham, UK.

Winter, A. J., and J. F. Hokanson. 1964. Effects of long-term feeding of nitrate, nitrite, or hydroxylamine on pregnant dairy heifers. Am. J. Vet. Res. 25:353-361.

Wolin, M. J. 1975. Interactions between the bacterial species of the rumen. Pages 134-148 in Digestion and Metabolism in the Ruminant. I. W. McDonald and A. C. I. Warner, ed. The University of New England, Armidale, Australia. 